\title{
Individualisation in Swedish adult education and the shaping of neo-liberal subjectivities
}

\author{
Andreas Fejes, Maria Olson, Lina Rahm, Magnus Dahlstedt and Fredrik Sandberg \\ Journal Article
}

\section{Tweet}

N.B.: When citing this work, cite the original article.

This is an electronic version of an article published in:

Andreas Fejes, Maria Olson, Lina Rahm, Magnus Dahlstedt and Fredrik Sandberg, Individualisation in Swedish adult education and the shaping of neo-liberal subjectivities, Scandinavian Journal of Educational Research, 2016, pp.1-16.

Scandinavian Journal of Educational Research is available online at informaworldTM: http://dx.doi.org/10.1080/00313831.2016.1258666

Copyright: Taylor \& Francis (Routledge): SSH Titles

http://www.routledge.com/

Postprint available at: Linköping University Electronic Press

http://urn.kb.se/resolve?urn=urn:nbn:se:liu:diva-133290

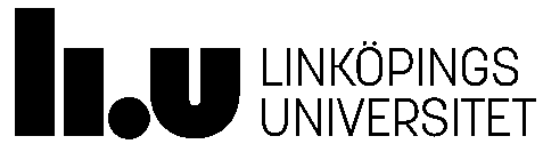




\title{
Individualisation in Swedish adult education and the shaping of neo-liberal subjectivities
}

Andreas Fejes, Linköping University, Department of Behavioural Science and Learning, Sweden (andreas.fejes@liu.se) - corresponding author

Maria Olson, Dalarna University, Stockholm University, University of Skövde, Sweden (maol@du.se)

Lina Rahm, Linköping University, Department of Behavioural Science and Learning, Sweden (lina.rahm@liu.se)

Magnus Dahlstedt, Linköping University, Department of Social and Welfare Studies, Sweden (magnus.dahlstedt@liu.se)

Fredrik Sandberg, Linköping University, Department of Behavioural Science and Learning, Sweden (fredrik.sandberg@liu.se)

\section{Full reference}

Fejes, A., Olson, M., Rahm, L., Dahlstedt, M., Sandberg, F. (2016) Individualisation in Swedish adult education and the shaping of neo-liberal subjectivities. Scandinavian Journal of Educational Research, doi: 10.1080/00313831.2016.1258666

\begin{abstract}
In this article we have analysed the ways a discourse on individualisation is taking shape within adult education in Sweden, how it operates, and what effects it has in terms of shaping student subjectivity. Drawing on a post-structural theorisation we analyse interviews with teachers and students in municipal adult education (MAE) and folk high schools (FHS). The analysis illustrates how both institutions contribute to the shaping of individualised subjectivities, although differently. At the end, a general question is raised about what happens with the democratic function of adult education in general, when a discourse on individualisation operates in the ways described, and more specifically, asks what is happening to FHS as an educational practice, that upholds its self-image as a last bastion of a collective notion of learning and subjectivity, and nurturing an educational practice of learning democracy?
\end{abstract}

Keywords: adult education, popular education, individualisation, folk high schools, municipal adult education, governmentality

\section{Introduction}

Marketisation of education is a global phenomenon (Ball, 2007; Ball \& Yodell, 2008; Burch, 2009) which has gained increased interest during the last three decades, not least in terms of research on school choice and its consequences (van Zanten \& Kosunen, 2013; Dumay \& Dupriez, 2013). Sweden stands out as a specifically interesting case, due to its historical social democratic heritage, in combination with having one of the most marketised education systems in the world (Lundahl, 2016). With the introduction of so-called independent schools ${ }^{1}$ and a voucher system in compulsory and upper secondary school in 1991, and free

\footnotetext{
${ }^{1}$ Independent schools are non-public in terms of ownership and they must be accepted as such through an application to and evaluation by the national agency of education. If accepted to launch a school in a municipality, they are then allocated a voucher, which is publically funded, for each student they recruit.
} 


\section{Accepted for publication in Scandinavian Journal of Educational Research}

school choice, an education market emerged. Furthermore, it became possible for private firms, such as large equity companies, to own schools and make profits through the voucher system (cf. Lundahl, Arreman, Holm \& Lundström, 2014). Since the early 1990s, the number of students enrolled in independent schools has increased, and today $26 \%$ of all students in upper secondary school are enrolled in an independent school (Swedish National Agency for Education [SNAE], 2015). In the case of adult education, we can see a similar development. As is the case in youth education, the number of adult education students enrolled with nonpublic providers is increasing, from $14.7 \%$ in 1997 to 45.7\% in 2014 (SNAE, 2015). However, there are also vital diverging points in relation to youth education. Instead of being reorganised through independent schools and a voucher system, the municipalities buy courses from public (municipal) or private providers through a procurement system, on shortterm contracts, thus creating a different kind of market.

Marketisation of education is a contemporary important factor that influences the way educational institutions are being organised. However, the different ways of organising and providing youth and adult education are also linked with and are an "effect" of historically established educational traditions of each specific educational site as well as of more general and multiple changes in society concerning questions of governance and ideas about what citizen (i.e. student subjectivity) is desired (cf. Lundahl \& Olson, 2013; Sandberg, Fejes, Dahlstedt \& Olson, 2016; Fejes, 2010). With the emergence of neo-liberal notions of governing, where the freedom of the individual becomes both the starting point and an effect of governing, a responsible, self-governing, and highly individualised citizen emerges (see e.g. Rose, 1999; Cruikshank, 1994). Such a citizen is shaped and moulded through a range of institutional practices, and adult education has been argued to be one site where this is especially prominent (see e.g. Fejes, 2006; Sandberg et al., 2016).

Discourses on individualisation is particularly notable in relation to Swedish MAE where, since the mid-1990s, there have been substantial changes towards a stronger focus on individualised and flexible forms of education, seen as necessary in order to meet the needs of each and every individual. Individualisation of adult education is here increasingly spoken of, on the one hand, as an organisational issue, where education should be delivered at all times and in forms adapted to the life circumstances and needs of adults. On the other hand, individualisation is spoken of in terms of making adult education more cost-effective, and in terms of increasing the number of students who succeed in their education (Ministry of education, 2013). In order to realise such notions of individualisation, municipalities are encouraged to procure MAE, thus engaging a wide range of providers (public, private companies, folk highs schools or study associations) in the delivery of courses, and in turn, offering students courses with different kinds of pedagogy, modes of teaching, didactic and communicative standards and other organisational varieties.

However, with discourses on individualisation operating within a neo-liberal notion of governing, the question becomes what "happens" with individualisation, i.e. what shape does a discourse on individualisation take? What "effects" does the discourse on meeting each individuals' needs and demands through organising adult education in certain ways, have in terms of shaping student subjectivity? This question becomes even more interesting to pose with different educational institutions engaged in the delivery of MAE. A discourse on individualisation might be expected to operate differently within different institutions, especially if we focus on Swedish FHS, where a collectivistic notion of education and learning has emerged as a central idea, with historical and politico-ideological trajectories dating back to the mid-1800s. 
The question then, in this article, is how does a discourse on individualisation take shape within adult education in Sweden, how does it operate and with what effects in terms of shaping student (citizen) subjectivity? Drawing on interviews with students and teachers in MAE and FHS, we are able to examine how such a discourse operates differently within these two institutions.

\section{Adult education in Sweden}

Folk high schools are among the institutions and practices described by the wide term 'popular education', and have historically (and still are) shaped as "free and voluntary", with great autonomy in shaping their own curriculum and methods of delivery. Folk high schools are the oldest adult education institution in Sweden, dating back to 1868, when the first school was created. The first schools emerged as places for the farmers' sons to learn the trade as farmers, later being picked up as an educational form where social movements schooled their members (e.g. workers' movement, the temperance movement, women's' movements, the Free Church movement). Today, there are 154 FHS in Sweden and together they provide a range of different kinds of courses, reaching from basic courses providing eligibility to enter higher education, targeting those who do not "fit" the regular school system - often with a working class background - to courses within the cultural arena, often with students who come from a middle class background (Nylander, 2014). FHS have traditionally, as well as today, been construed as places offering a different kind of pedagogy, where the group is central for the individuals’ development (see e.g. Paldanius, 2014).

The state funds a substantial part of the folk high schools' activities (as part of the funding for popular education, which is distributed to folk high schools and study associations through the national council of adult education). The state aim of popular education is to (SFS, 2015) "give everyone the possibility, together with others, to increase their knowledge and 'bildung' for personal development and participation in society". Among the more specific aims stated, it is suggested that FHS should support activities that contribute to the strengthening and development of democracy, increasing people's influence on their life situation, creating engagement to participate in the development of society, and closing educational gaps between individuals and groups of people. The aim is thus quite broadly formulated in relation to issues of social justice, democracy, citizen subjectivity and society.

Besides the above mentioned kinds of courses funded directly by the state, and which the FHS have considerable autonomy to shape without any state-organized curriculum, $16 \%$ of the activities of the FHS are funded by other means, e.g. by delivering courses within the frames of MAE (which is funded by municipalities). Thus, FHS are engaged in delivering formal (MAE courses) as well as non-formal (regular FHS courses) adult education courses.

Formal adult education in Sweden did not emerge in any clear institutionalised form until 1968 when MAE was created. Originally, MAE was shaped as evening courses for the "talented few" who had the ability to work full time and study in the evenings in order to attain the knowledge necessary to pass exams for compulsory and upper secondary school diplomas (Fejes, 2006). In the early 1970s the target groups of MAE shifted and became those farthest away from the labour market, and those with the lowest levels of educational attainment. The pedagogy of MAE has been described as similar to upper secondary schooling, and has been criticised for not adapting its organisation towards the needs of adults (Lumsden Wass, 2004). Such criticism was one reason for the state to initiate the adult education initiative in 1997, which would encourage municipalities to re-organise their MAE 


\section{Accepted for publication in Scandinavian Journal of Educational Research}

in order to better adapt to students' needs, which partly led to a greater degree of individualisation of education. Thus, today, the organisation of MAE is often described as flexible and adapted to the needs of each and every individual student.

The state's aim in MAE is regulated by the school law and has not changed much over the years. The law states that MAE should

support and stimulate adults in their learning. They should be provided with opportunities to develop their knowledge and competence, with the aim of strengthening their position in work as well as social life, and of contributing to their personal development. The starting point for the education should be the individual's needs and ability. Priority should be given to those with the lowest level of education”. (SFS, 2010)

The main task of MAE is, thus, to help students who previously failed their schooling and/or who do not have qualifications from compulsory and/or upper secondary school. They could include migrants as well as those who have previously taken part in the Swedish educational system. Secondly, adult education should shape individuals who can partake in life as active democratic citizens and, thirdly, it has the function of preparing students for the labour market. However, there has been a shift in emphasis among these three functions and the relationships between them since the creation of MAE in 1968 (Rubenson, Tuijnman \& Wahlgren, 1999). Although increased stress has been put on the adult students' opportunities to experience democracy in their everyday lives in education in the two most recent curricula of 1994 and 2011 (SNAE, 2006, 2011) the focus of MAE has - in the last decade increasingly been on its labour market function and the shaping of an employable workforce (see e.g. Fejes, 2010).

Taken together, these two forms of adult education in Sweden have quite different aims laid down by regulation, and partly different historical trajectories. However, with changes in the last two decades, where MAE has opened up to different forms of providers, and where some folk high schools have started to deliver MAE courses parallel to the other courses they deliver, they are to greater extent than before delivering courses which are governed by a national curriculum, which could be argued to counter the idea of popular education as "free and voluntary". Of interest here is thus, to analyse how a discourse on individualisation takes shape and operate, and with what effects in these two different institutional practices today.

\section{Theoretical and methodological considerations}

In order to analyse how discourses on individualisation operate within adult education in Sweden, we draw on a post-structural and discursive theorisation inspired by the work of Michel Foucault (1972, 1980, 2007), and specifically education scholars who have developed and mobilised such a perspective (Fejes, 2006, 2010; Nicoll, Fejes, Olson, Dahlstedt \& Biesta, 2013; Olson, Fejes, Dahlstedt \& Nicoll, 2015; Simons \& Masschelein, 2008). Concepts such as discourse, governmentality and subjectivity, here become central analytical concepts. In this approach, 'discourse' includes what is said through speech or writing, but it is more than this. A discourse is not just the signs of language, but a system for the formation of a group of statements that is not limited to what is being said (Foucault, 1972). In relation to individualisation, discourses are constituted through statements that emerge as possibilities for speech, events and action-taking at a particular time and location. These statements are considered as entities that allow signs to assign specific and repeatable relations to objects, 


\section{Accepted for publication in Scandinavian Journal of Educational Research}

subjects and other statements. These relations have different features and a vital feature is the construction of (citizen) subjectivity.

Through discourses of individualisation, student subjectivity emerges. Subjectivity is here not pre-defined, nor does subjectivity have any essence. Rather, subjectivity emerges through the way students and teachers describe themselves and others. In other words, this is a decentred notion of subjectivity, and such subjectivity is enmeshed in power relations, which makes these relations possible. We then have a governing relation, and can talk about the analytical concept of governmentality. With the concept of governmentality, the aim is to broaden the taken for granted notion that governing is something conducted by the state (see Foucault, 2007). Here 'government' is not only concerned with governing through state control, lawmaking, policy decisions and institutional curriculum practices and so forth, but occurs in and through discourses and practices which inform our everyday actions and are drawn on in our relations to ourselves (Fejes \& Nicoll, 2008). Foucault (2007) uses the concept of the 'conduct of conduct' to analyse how people are constituted as governors of others and the self. Governmentality ascribes the repetitions 'imminent' to this relationship, 'whatever the level of analysis being considered (parent-child relation, individual-public power, populationmedicine, and so on' (Senellart, 2007, p. 389). Governing then is the guidance of conduct, where behaviour attempts to shape the field of possible action in relation to these repetitions. This makes it possible to approach the issue of how student subjectivities are shaped through discourses on individualisation as something other than that which only implies this to be a question of governing by the State, i.e. by policy, politico-juridical regulation and curriculum. The perspective allows for the involvement of policy or a curriculum to be just one element in a wider discursive network of words and deeds that shapes student (citizen) subjectivities.

In order to identify how discourses of individualisation operate and how they shape student (citizen) subjectivity, we have conducted interviews with students and teachers at one FHS and one municipally run school of MAE. The FHS selected provided opportunities to obtain a varied sample in terms of students and teachers enrolled and working in different courses, and also provided a site where we were granted access. Here, we interviewed six teachers and 26 students who partook in either the basic course or a course in youth creation work. These courses are not specifically delivered within the frames of MAE, but are two of the regular course offerings of FHS. The basic course provides eligibility to apply to higher education, and is in that sense comparable to courses within MAE. The youth leader creation program is a vocational program, with some similarities to vocational courses within MAE. However, our selection was mainly based on the premise that we could be provided with a "classical" FHS practice, which might provide an opportunity to potentially identify a distinctly different way that individualisation operates as compared to MAE.

One of the main municipally run adult education schools in one of the major cities in Sweden was selected for the study. The school was chosen due to it being a "classical" example of a municipally run school today, offering a range of different courses (i.e. many providers on contract with the municipalities are specialised, only offering a limited number of courses, and those providers delivering the widest range of courses are often run by the municipality themselves). We were granted access to students and teachers within social science courses, and in total we interviewed six teachers and 26 students.

The selection of student interviewees in both sites was based on who was willing to partake. Two of the researchers were responsible for one setting each. The project was introduced to students during lessons at the beginning of the semester, and the researchers were present on 


\section{Accepted for publication in Scandinavian Journal of Educational Research}

site during lessons and coffee breaks, on and off during one semester. By immersing themselves in these sites, access to student interviewees was made easier, as students had opportunities to learn more about the project, what it meant to partake in interviews and so on. Ethical guidelines were used including informed consent, anonymity, as well as the possibility to cease participation at any time.

The interviews were semi-structured, and questions posed to students concerned matters such as why they participated in adult education, and how they felt about their studies and wider lives as citizens. In the teacher interviews, we asked about their work as teachers, their views on students and how they thought that the teaching practice prepared students for a life as citizens. Interviews were transcribed verbatim, providing approximately 1000 pages of transcripts, and the names of the informants were anonymised through encoding with fictitious names.

A discursive analysis was adopted in which the interview transcript was seen as text (Foucault, 1980, 2007; Fejes, 2011; Fejes \& Nicoll, 2008). Such an approach means that what people say is based on the concepts, meanings and language that are made available to them through discourse. The analytical focus was thus on identifying regularities of descriptions in the interview transcripts, in order to identify how discourses on individualisation operate and with what effects in terms of shaping citizen subjectivity. In the reading of transcripts, attention was directed at recurrent concepts, meanings, and relationships formed through regularities both within and between descriptions. We saw these as being constitutive of the objects that they described. Of special interest were the material and discursive conditions that make such constitution possible.

Our analysis resulted in the categorisation of three different, but interrelated, ways that adult education is construed as space that shapes and moulds student citizen subjectivities, namely adult education as a space to shape oneself as a learning subject; teaching practice; and spaces for learning. Furthermore, we identified several discursive and material conditions making such shaping and moulding possible. In the following four sections we introduce the analysis where interview extracts are used as exemplifications of our analysis and argument. As previously mentioned, in order to keep the anonymity of interview participants, we have chosen to use fictitious names.

\section{Adult education as a space to shape oneself as a learning subject}

Through interviews with students and teachers, regularity emerges where MAE is shaped as a place where individuals meet up in order to realise their individual trajectories, whether these are further studies in higher education or entering into the labour market. Interaction and socialisation with peers do not emerge as important parts of the studies, regardless of the purpose for studying. Life as a student comes into being as an individual process rather than a collective one, which comes to the fore in the very relationship between individuals and the MAE to which they are subjected. The relationship is shaped and supported when the young adult students compare their experiences of MAE with their previous experiences of studying in upper secondary school as youths. As the student Anna puts it: "I'm here like, as an individual or something...you think about yourself and your future”. Another student, Pernilla, argues:

I see this [participation in MAE] as going from point A to point B. Of course you attend the lessons, but I'm not going to put too much time and effort into engaging in new relationships and...to stay in the cafeteria. That's not the experience I'm looking for. I wish to get my grades, and I wish to get going with this [studying] again, I wish to progress. (Pernilla) 


\title{
Accepted for publication in Scandinavian Journal of Educational Research
}

One of the teachers, Bengt, describes studying at MAE in this way:

\begin{abstract}
At MAE, it's not the same [as upper secondary school]. At MAE students are there more as individuals than as a group, they are more fragmented, and there is more room for them to be themselves. For better or worse, you are not forced, or you do not have to commit yourself [to things other than studying], at the same time, you could if you wanted to. But there is a risk at MAE, and this sounds a bit negative, that students may distance themselves [from peers], that they are not drawn into their studies. You have to muster a greater will to be there, both concerning attendance and engagement or results. (Bengt)
\end{abstract}

Bengt also makes a comparison between how MAE was, according to him, 20 years ago, and how things are today. He argues that before there was "more continuity where one should be part of this community, while this is not as apparent today". Both the students and the teacher here position MAE in opposition to a community or collective. MAE is something one does because one "thinks about oneself and one's future" and it is not something one does in order to create "new relationships". Here, the focus is on individual goals, and MAE, accordingly, becomes a means to an end, where the assignment of MAE stands out as an almost entirely instrumental enterprise directed towards the individual's future.

Turning to student interviews in the folk high school (FHS), regularity regarding their choice of studying at folk high schools arises in terms of being based on more collective ideas of studying and of life as compared to their counterparts in MAE. The folk high students' study choice is often described in terms of finding an education with a strong structure and where a community of peers is offered.

\begin{abstract}
Yes, I thought it was good, a good fellowship, good teachers, and such things. And that made me want to try. I wanted to improve my grades in order to make it... and I could do it really, and be more motivated. (Elin)

You are also very engaged in issues pertaining to the school here. It could be anything from the food in the canteen, to how lessons are planned. It's a very open climate here. You can feel that you are more than a student here. (Alim)
\end{abstract}

Here, as in MAE, there are students studying in order to be eligible to apply for higher education. However, rather than describing themselves as being in a place where they proceed quite instrumentally from point A to B, they attend FHS as it is a place with a "good sense of community", and a place where one is "more than a student". Folk high schools are here construed as a space for collective educational work rather than as a space of separate individuals instrumentally moving towards their individual educational and/or future goals of different kinds.

However, there are irregularities in the interviews when comparing teacher interviews with students' in FHS. The FHS teachers describe students as highly individualistic, and not very mature. The students stand out as irresponsible, in the sense of not taking responsibility for the common good in their education. As Gabriel and Lars, two of the teachers, argue:

Now it is like some secondary school class. They can't do anything on time and they can't help each other as they have enough to handle themselves. Then you hope that some of them will grow and change, but it can't happen yet, it is like talking to... I don't know, it is like, we have for many years had problems with coffee mugs at this school. Then it is like, if I tell you, OK, there is a coffee mug standing there at the table, could you bring it with you when you leave? "No, it is not my mug". That kind of answer is what you get. They are so damn focused on themselves. Only on themselves. "I have not done that”, and such answers you didn’t get 10-15 


\section{Accepted for publication in Scandinavian Journal of Educational Research}

years ago. Then it was more about fellowship and community. So, those who are young now, they are different I believe. (Gabriel)

We have several students who maybe have an attendance rate of 40-50-60 percent, and they say "I have never had such a high attendance rate in school before, I am thriving for the first time in school, I'm treated like an adult”. But you are not really an adult, if you define an adult as a person who can take care of herself. Age-wise they are adults, but not socially or emotionally. (Lars)

Here we can see how the folk high school students, despite describing themselves as acknowledged as adults, are not really depicted as such by the teachers. Students are rather construed as not meeting the teacher's ideals of learning and community building. According to the teachers, students mostly think about themselves and not of anything else, such as the greater good of the local community at school.

\section{Teaching practice - instrumentality and reciprocity}

Turning to how the teaching practices of MAE and folk high schools are described, we can see how different student subjectivities are shaped and formed. In MAE, regularity of description emerges regarding teaching practices, which in student interviews are shaped as a one-way communication, where students attend and quietly listen to what the teacher says, in order to be successful in reaching their individual goals. As two students express it:

Here at MAE, you choose to study. Most of the students who come here study and they are quiet in class, and they listen, and they attend the exams. (Andris)

There are a lot of people here. It's hard to make contact with other students. If you attend a class, you wish to listen to the teachers. And then you can't sit there [at the lessons] and talk to other students. And after the lesson, one student is going home, the other is going to another class, and the third is having lunch. (Markus)

Here, according to the students, they are "quiet" during the lessons, "listen to the teachers" lecturing and "arrive for the exams". There is no space in the lessons to chat with peers, as this would disrupt the students' focus on passing exams in order to reach the individual goals set for the future. There is an instrumental logic construed. The goal-oriented students attend MAE in order to reach individual goals, and teachers provide a space for them to be quiet, to listen and to do exams in order to reinforce the students' orientation. Such instrumentality is further supported when some students at the folk high schools who previously attended MAE, compare their experiences from MAE with their current experiences of studying at folk high schools. As Alim, one of the students, expresses it:

It's a very nice school, as I said before, you can express your opinions a bit more. It feels very open here, and it's nice. If you compare it to MAE, I attended MAE last year, and it was very rigid and boring, if I may say. It was really crappy. You went there the first day, and there was a roll call and then directly the teacher conducted a review using the blackboard. (Alim)

Here, MAE is construed as a place of one-way communication, efficiency and goal orientation. In relation to folk high schools, on the other hand, regularities of description emerge where FHS come into being as places that are "open" and "cool". Other students at folk high schools describe the teaching practice as more of a collective work, with debates and discussions, while at the same time communicative, dialogic working forms are used, as expressed by two students: 


\section{Accepted for publication in Scandinavian Journal of Educational Research}

What's really good at this school, and especially in the class I'm attending, is how well discussions work, you can really feel, "aha”, he or she thinks in that way, and that's one way you could think. I think that's really good. (Emma)

We often use "rounds" which I like. Then everyone is allowed to speak. We sit in a ring. And then we say: the ball is in the air, and then someone can catch the ball and say "I take the ball" and then that person starts speaking, in relation to the issue of the day. (Simon)

Here we can see how discussions are described as a way for students to have their own perspectives challenged, and to learn to respect the opinions of others. The use of "rounds" as a dialogical working method in teaching practice is used to provide space for each student to give voice to her or his thoughts and ideas. Teachers themselves also, through the interviews, actualise such teaching practice where a sense of belonging and the use of dialogical working forms are important parts. As one teacher expresses it: 'the 'how' question is more important than the 'what' question". And in a similar way, another teacher, Lena, makes the following statement:

Popular education.... for me it is about extracting - this is something positive - as much information as possible from all persons in order to turn it into some kind of individual knowledge. (Lena)

These folk high school teachers talk about the importance of using pedagogic working forms that engage all students in order to make the production and consolidation of knowledge possible. Knowledge is here construed as relational, and also as reciprocal. Thus the forms of teaching practice in MAE and folk high schools are construed quite differently; the former is described as more of a one-way communication and quite instrumental, while the latter stands out as more of a collective, reciprocal place for knowledge production.

A logic is created in the transcripts, where the pedagogical ideals of the FHS teachers are shaped as partly depending on whether students attend the classes or not. However, the teachers describe a general decline in student attendance rate and thus, consequently, resulting in the teaching practice and teachers becoming more traditional in terms of one-way communication. A learning logic in terms of sender-receiver-orientation emerges. This is expressed by Gustav, one of the FHS teachers:

\footnotetext{
The attendance rates have lowered, and that has repercussions on everything else. It is more important than one might initially believe. You think that if someone is absent, it doesn't matter so much. If there are only a few people absent, it might not be a problem, but if many are absent, lesson plans do not work, my planning does not work... We have been forced to become more traditional in the general program... because of the demands concerning the deliverance of eligibility [to higher education] (Gustav)
}

Gustav describes the low attendance rate as being a huge challenge to his ability to carry out his pedagogical, communicative teaching ideals. However, there is not only a dissonance between the FHS teacher statements about their ideals and the FHS students, but also between students' and teachers' statements.

\section{Spaces for learning - individual and collective}

Besides describing life in classroom rather differently, students in the two different adult education practices also describe life at school, outside teaching practice, quite differently. In MAE, study life is, as already noted, construed as an individual and instrumental enterprise. But regularities of description also emerge regarding life outside of school, where collective forms of learning through homework outside teaching practice seem to be limited at the same 


\title{
Accepted for publication in Scandinavian Journal of Educational Research
}

time as learning through group work comes into question as quite complicated due to a lack of informal meetings between students. As explained by one student:

\begin{abstract}
What I miss at MAE for example - and it's something which one probably should learn from life as a student in academia - is studying together. But what do you do then? Suddenly we have different roles in life, which could be nice for the person with a job or family or stuff. But I feel a lack at MAE, that I don't have any real connections with those with whom I work, which makes group assignments much more difficult. (Fredrik)
\end{abstract}

Here, MAE is shaped as a learning space where one does not "have a real connection with those with whom I work", which makes group work harder for some students. A spirit of community stands out as lacking. This kind of individually oriented shaping of learning spaces outside of teaching practices is not apparent in the interviews with students at the folk high schools. Rather, for these students, life outside the classroom is described as an important part of their learning experience. Regularity of description here emerges in terms of a sense of belonging and community, actualised for instance by having lunch together, or by organising events for all students at the school, as expressed by Helen and Mika, two of the students:

It's much about conviviality, and to be together and getting to know other people. And people on the youth creation leader program organise field days, and activity groups and such. It seems that they wish to create a community across the program at the school. They organise a lot of movie nights, groups, which you can attend just for community building and sense of belonging, I think. So I would like to say that the school puts a lot of effort into community building. (Helen)

All of us getting together, to eat lunch together, that we are all a big group, as friends and I think, that is what being a citizen is to me at this school, this sense of belonging. (Mika)

Here, folk high schools are shaped as learning spaces where one works to create a sense of conviviality and belonging among one self and other students, almost like being a "big group... as friends”. In this respect, MAE and folk high schools are created in different ways. The differences stand out in terms of how students learning life outside teaching practice is shaped, but also within the framework of the educational practice itself, as described by MAE and FHS students.

\section{The shaping of student subjectivities - material and discursive conditions}

The shaping of individualised and more collective student subjectivities in MAE and FHS respectively is made possible by different material and discursive conditions. In MAE, the challenge to find a common ground, as well as shaping adult studies as a collective process, comes to the fore through regularities of description regarding certain material conditions that are being actualised, such as being course-based, where students rush between different classes, and educational courses delivered by different educational providers that are located in different parts of the city. As one student, Jonny, describes it; "Here in MAE, you have different classes all the time, so you do not really get close to each other" (Jonny). Statements from the interview with Kenneth, one of the MAE teachers, further supports such challenges in MAE:

First, I meet 25 students in history and then I meet 25 other students in social science, but they have nothing to do with each other. By the way, two of them do both classes, but they are the only ones, but that doesn't mean they are necessarily friends. (Kenneth)

Here, due to having different classes all the time, students do not "really get close to each other", and MAE students in different classes do not have anything to do with each other. 


\title{
Accepted for publication in Scandinavian Journal of Educational Research
}

Thus, as a teacher in history and social science in MAE argues, the students in both subject teaching groups differ (which is not the case in upper secondary school). Thus, continuity in teaching is made more difficult at MAE than in FHS. This is further reinforced when teachers describe the MAE practice where students are allowed to enrol continuously, during the running semester, which leads to the creation of new student groups all the time. In addition, fluctuation in attendance rates is also argued to influence continuity in teaching.

\begin{abstract}
It's very flexible in the sense that you begin at different dates. There is a small core group, who begin and end at traditional dates, but then there are big changes during the semester in terms of student enrolment. This might be negative for teaching, as you don't get any continuity, you don't get any team spirit. And this has to do with the course format [in MAE], i.e. we do not have cohesive groups that make it possible for us to work with the entire group and its development. (Anders)

In some lessons five students attend, and sometimes the entire student cohort attends, and then they are usually 25. But usually there are ten to fifteen students attending. And everyone always has reasons [not to attend]; suddenly one is home with a sick kid. You wouldn't find that at upper secondary school in the same way. People are sick or people have been given work schedules which do not allow them to attend on Wednesday, so there are reasons for most of them [absences]. (Kenneth)
\end{abstract}

Here, material conditions concerning enrolment and attendance are raised as serious challenges for MAE teachers. These conditions further reinforce the individualisation of student subjectivity, and make - as aforementioned - group work, sense of belonging and community building more complicated or maybe even impossible in relation to other educational forms mentioned.

In folk high schools, other material and discursive conditions make a different student subjectivity possible. Here regularities of description emerges regarding the very organisation of studies, where classes of students follow each other throughout the educational program, thus making continuity of teaching and learning easier or even more likely than in MAE, as expressed by Olle, one of the folk high school teachers:

If you attend four terms in the same class, if you work with leadership and such things, then it's really worth putting time and effort into working with the group and group processes. ...Continuity is of great importance too, and it is worth working with personal development and other things I relate to popular education. (Olle)

As indicated here, working with classes of students who follow each other over an entire program makes possible a focus on working with the group and the group process, as well as the individual, in order to achieve the educational goals of the folk high school, its teachers and students. Hence, such a structure not only makes possible a more collective-oriented view on knowledge creation and learning, but also a more collective and community-related student subjectivity.

However, at the same time, regularities in the addressing of the student groups arise in the interviews with FHS teachers, where classes of students are described as being too homogeneous. As most of the adult students are described by the teachers as very young, coming directly from upper secondary school, without any major labour market experience, it is argued to be a challenge to realise pedagogical ideals of dialogue based communication related to content or "real world" cases based on students' different experiences in the classroom's teaching practice. As Gustav, a FHS teacher expresses it: 


\begin{abstract}
When I started here, there was a perfect mix of different ages. There were also those who were 50-60 years old, it was unusual, but they were very welcome. There were those who were 20 years old, but this range was very good in that way. And there's not anything wrong with being of any age, but there is also this mix, which I find exciting, and dynamic...And it's one thing if there's one or two in each class [weak students], then there are many peers there, but it's almost easier for them when they get feedback like "Fuck, you need to attend, oh my God, what are you doing?” That's what a peer might say, I guess. And they do have that kind of relationship and culture in the group. But those [with a high attendance rate] who are often here, they no longer have the energy to take on that role, as there are so many [weak students] in each group. (Gustav)
\end{abstract}

Gustav, among other FHS teachers, describes heterogeneity as important in order to create a good basis for exchange and development of learning processes and knowledge in the educational site of FHS. Peer to peer learning is made difficult here due to the constitution of the group of students, which they consider to be harmful for the spirit of peer learning as well as for teaching.

\title{
Concluding discussion
}

In this article we have focused on the ways a discourse on individualisation takes shape within adult education in Sweden, how it operates and with what effects in terms of shaping student (citizen) subjectivity. Our analysis illustrates how an individualised student subjectivity is shaped through discourses operating and producing these subjectivities in two different educational institutions. However, the shaping of such student subjectivity emerges differently within the two institutions. Within MAE, the individualised student is clearly constituted through the way that the studies are said to be organised, as well as through the way students describe their reasons for being involved in this educational practice. A continuous intake of students, low attendance rates, and students being greatly, and to some extent instrumentally focused on studying are all conditions that contribute to MAE coming into being as an educational space with few possibilities for the students to be involved in collective forms of learning and working with others, inside and outside the classroom or other sites for learning. Thus, MAE offers meagre possibilities for collectively oriented subjectivity shaping. In FHS, on the other hand, where collective and community-oriented forms of teaching and learning are described as an ideal, both inside and outside the classroom, the shaping of a more collective form of subjectivity is indicated. Nonetheless, an individualised subjectivity is also being created in the FHS. Such creation is partly related to the regularities of description regarding the quite homogeneous student population that to a small extent provides opportunities for relational, communicative and pedagogical shared modes of educational working and learning. Regularities in teachers' description of students being egoistic and immature further reinforce this.

However, the more collectivised discourse emerging in the transcripts from interviews in the FHS needs further problematisation. On the one hand, regularities emerge in both student and teacher interviews regarding FHS coming into being as a collective, relational and community-oriented space for learning, which is in line with the prevailing self-image mobilised within folkbildning (popular education) (see e.g. Gustavsson \& Wiklund, 2013; Johansson \& Bergstedt, 2015). Thus, one could be inclined to argue that a discourse on individualisation does not really penetrate FHS, and that FHS seem to have been able to keep their "core" values (i.e. mobilising a different discourse). But, on the other hand, irregularities emerge in the interviews when comparing student and teacher interviews regarding who the student "is". FHS students describe themselves as partaking in collective forms of learning and educational activities both during and after lessons, while the FHS teachers describe students as immature, egoistic, with a low attendance rate, and too individualised and self- 
centred in their behaviour. Student groups are also described as very homogeneous. Thus, a discourse on individualisation in terms of students as egoistic and self-occupied emerges in FHS parallel to a collectivised discourse on learning and teaching. Put more bluntly, the students are not the kind of students teachers wish for, or rather, students do not meet teachers image of an ideal student.

The repetitions emerging in interviews with students and teachers in MAE also provide interesting room for discussion when they are compared with previous studies on MAE. For example, in a study of MAE carried out in the late 1990s one of five reasons for participation identified among (interviewed) students, was socialising and making new friends (e.g. Assarsson \& Sipos Zackrisson, 2005). As we have illustrated in our analysis, quite the opposite was the case in our study. Rather than constructing MAE as a place for collective activities, whether they are socialising or joint studying, MAE is shaped as a place for the individual to create a goal-oriented future, which stands out as quite instrumental and nonrelational, with little or no interaction among peers. However, a cautious note is that our focus here is on analysing interview transcripts as text, rather than reading them, or taking an interest in what "really" happens. One could probably expect students in MAE to interact and socialise with each other during and after classroom lessons. However, the repetitions emerging in our interviews were quite distinct, which raises questions and strongly supports the shaping of a rather clearly individualised discourse on Swedish adult education and its students.

Taking on the analysis in this study questions can be raised for the future regarding the alleged aims of adult education, and the balancing between these aims. With its manifold goals, laid down by law to prepare students for life as democratic citizens, as well as preparing them for further studies, and work life, MAE seems to have turned into a practice that emphasizes and more or less exclusively focuses on the labour market function (Sandberg et.al., 2016; Fejes, 2010). With the current process of marketisation in Sweden and elsewhere, shaped within a neo-liberal notion of governance (Rose, 1999), adult education has becomes a commodity in a market, where municipalities become the customers, and students are positioned as those who actively need to choose their education (wisely) (Fejes, Runesdotter \& Wärvik, 2016). Thus, although individualisation is spoken of on a policy level as mainly about adapting the organisation of adult education towards the needs of each individual, individualisation becomes something different, as well as persuasive in terms of its effects when focusing on the wider discourses, as well as on how such discourses emerge in students' and teachers' statements. The persuasiveness of such discourse on individualisation is particularly visible when focusing on FHS. Despite the FHS's historical trajectory, and strong identification with certain pedagogical ideals (discourses) that orient towards the relationship between education and life in society, individualisation emerged repeatedly in the FHS teachers' descriptions. Our analysis, hence, not only raises the general question about what happens with the democratic function of adult education in general, but more specifically, it also raises the question of what is happening with FHS as an educational practice, upholding its self-image as a last bastion of a collective notion of learning and subjectivity, and nurturing an educational practice of learning democracy?

\section{References}

Assarsson, L., \& Sipos-Zackrsisson, K. (2005). Iscensättande av identiteter i vuxenstudier [Staging identities in adult education]. Linköping: Linköpings universitet. 


\section{Accepted for publication in Scandinavian Journal of Educational Research}

Ball, S. (2007). Education plc: Understanding private sector participation in public sector education. London: Routledge.

Ball, S. J., \& Youdell, D., (2008). Hidden Privatisation in Education. Brussels: Education International. Available at:

http://download.ei-ie.org/docs/IRISDocuments/Research\%20Website\%20Documents/200900034-01-E.pdf.

Burch, P. (2009). Hidden markets: The new education privatization. London: Routledge.

Cruikshank, B. (1994). The will to empower: Democratic citizens and other subjects. Ithaca: Cornell university press.

Dumay, X., \& Dupriez, V. (2014). Educational quasi-markets, school effectiveness and social inequalities. Journal of Education Policy, 29(4), 510-531. doi: 10.1080/02680939.2013.850536

Fejes, A. (2011). Confession, in-service training and reflective practices. British Educational Research Journal, 37(5), 797-812. doi:10.1080/01411926.2010.500371

Fejes, A. (2010). Discourses on Employability: Constituting the Responsible Citizen. Studies in Continuing Education, 32(2), 89-102. doi:10.1080/0158037X.2010.488353

Fejes, A. (2006). The planetspeak discourse of Lifelong learning in Sweden - what is an educable adult? Journal of Education Policy, 21(6), 697-716. doi:10.1080/02680930600969266

Fejes, A \& Nicoll, K. (Eds.). (2008). Foucault and lifelong learning: governing the subject. London: Routledge.

Fejes, A., Wärvik, G-B., \& Runesdotter, C. (2016). Marketization of adult education: principals as business leaders, standardised teachers and responsibilised students. International Journal of Lifelong Education. doi:10.1080/02601370.2016.1204366

Foucault, M. (2007). Security, territory, population. Lectures at College de France 19771978. New York: Palgrave Macmillan.

Foucault, M. (1980). Michel Foucault: Power/knowledge, selected interviews and other writings 1972-1977. Brighton: Harvester Press.

Foucault, M. (1972). The archaeology of knowledge. New York: Harper.

Gustavsson, B. \& Wiklund, M. (Eds.). (2013). Nyttan med folklig bildning. En studie av kapitalformer i folkbildande verksamhet [The value of popular education: A study of forms of capital within popular educational activities]. Lund: Nordic academic press.

Johansson, L., \& Bergstedt, B. (2015). Visions Unite through the Concept of Democracy: The School and the Popular Adult Education. Scandinavian Journal of Educational Research, 59(1), 42-57. doi:10.1080/00313831.2013.838697 


\section{Accepted for publication in Scandinavian Journal of Educational Research}

Lumsden Wass, K. (2004). Vuxenutbildning i omvandling. Kunskapslyftet som ett sätt att organisera förnyelse [Adult education in time of change: The adult education initiative as a way to organize renewal]. Göteborg: Acta Universitatis Gothoburgensis.

Lundahl, L. (2016). Equality, inclusion and marketization of Nordic education: Introductory notes. Research in Comparative \& International Education. doi:10.1177/1745499916631059

Lundahl, L., Arreman, I.E., Holm, A-S., \& Lundström, U. (2014). Gymnasiet som marknad [Upper secondary school as a market]. Stockholm: Boréa Bokförlag.

Lundahl, L., \& Olson, M. (2013). Democracy Lessons in Market-Oriented Schools: The Case of Swedish Upper Secondary Education, Education, Citizenship and Social Justice, 8(2), 201213. doi:10.1177/1746197913483684

Ministry of Education. (2013). SOU 2013:20, Kommunal vuxenutbildning på grundläggande nivå: En översyn för ökad individanpassning och effektivitet [Basic municipal adult education: A review in order to increase individualisation and efficiency]. Stockholm: Ministry of Education.

Nicoll, K., Fejes, A., Olson, M., Dahlstedt, M., \& Biesta, G. J.J. (2013). Opening discourses of citizenship education: A theorization with Foucault. Journal of Education Policy, 28(6), 828-846. doi:10.1080/02680939.2013.823519

Nylander, E. (2014). Skolning i Jazz: Värde, selektion och studiekarriär vid folkhögskolors musiklinjer [Value, selection and study careers in music courses at folk high schools]. Linköping: Linköpings universitet.

Olson, M., Fejes, A., Dahlstedt, M., Nicoll, K. (2015). Citizenship discourses: production and curriculum, British Journal of Sociology of Education, 36(7), 1036-1053. doi:10.1080/01425692.2014.883917

Paldanius, S. (2014). Sär-skild folkhögskolepedagogik? Erkännandets didaktik i Folkhögskolor [A special folk high school pedagogy? A pedagogy of recognition at folk high schools]. Rapporter i pedagogik 20. Örebro: Örebro universitet.

Rubenson, K., Tuijnman, A. \& Wahlgren, B. (2009). Från Kunskapslyftet till en strategi för livslångt lärande. SOU 1999:141 [From an adult education initiative to a strategy for lifelong learning]. Stockholm: Utbildningsdepartementet.

Rose, N. (1999) The powers of freedom: Reframing political thought. Cambridge: Cambridge University Press.

Sandberg, F., Fejes, A., Dahlstedt, M., \& Olson, M. (2016). Adult education as a heterotopia of deviation: a dwelling for the abnormal citizen. Adult Education Quarterly, 66(2), 103-119. doi:10.1177/0741713615618447

Senellart, M. (2007) Course context, in M. Foucault (Ed.) Security, territory, population: Lectures at the College de France 1977-1978 (pp. 369-401). Basingstoke: Palgrave MacMillan. 


\section{Accepted for publication in Scandinavian Journal of Educational Research}

SFS. (2010). Svensk författningssamling. Skollagen [The school law]. Stockholm: Swedish government. [Swedish law. The school law].

SFS. (2015). Svensk författningssamling. Förordning om statsbidrag till folkbildningen (2015:218) [Law concerning state funding for popular education]. Stockholm. Swedish government.

Swedish National Agency for Education. (2015). Komvux - elever och kursdeltagare riksnivå. [Municipal adult education - students and course participants nationally]. The Swedish national agency for education Retrieved August 7: http://www.skolverket.se/statistik-och-utvardering/statistik-i-tabeller/komvux/elever-ochkursdeltagare

Swedish National Agency for Education. (2006). Lpf94. Läroplan för de frivilliga skolformerna, Lpf 94 [Curicculun for upper secondary school and municipal adult education]. Stockholm: Fritzes.

Swedish National Agency for Education. (2011). Läroplan för grundskolan, förskoleklassen och fritidshemmet, Lgr11 [Curriculum for compulsory school, pre-school and recreation centres]. Stockholm: Fritzes.

Simons, M., \& Masschelein, J. (2008). The governmentalization of learning and the assemblage of a learning apparatus. Educational Theory, 58(4), 391-415. doi:10.1111/j.17415446.2008.00296.x

van Zanten, A., \& Kosunen, S. (2013). School choice research in five European countries: the circulation of Stephen Ball's concepts and interpretations. London Review of Education, 11, 239-255. doi:10.1080/14748460.2013.840984

\section{Bios}

Andreas Fejes is Professor and chair of Adult Education research at Linköping University, Sweden. Fejes has published extensively on issues pertaining to adult education and lifelong learning, mainly drawing on post-structural theorisations inspired by the work of Michel Foucault. His current research interests relates to citizenship education within and beyond adult education; marketisation of adult education; and the bibliometrics of education research. Fejes is one of the founding editors of the European Journal for Research on the Education and Learning of Adults (www.rela.ep.liu.se).

Maria Olson is Professor in Educational Work at Dalarna University/Stockholm University, Sweden. Her research centres on the relationship between citizenship and education, with special interest on policy and citizen formation. With point of departure in a post structural framework with different theoretical and philosophical elaborations, her research covers historical and present times of national, European and global identity making inside and outside of education.

Lina Rahm is a doctoral student in education specialising in adult learning at Linköping University, Sweden. Her doctoral work concerns issues of citizenship in relation to popular education and digitalisation. 
Magnus Dahlstedt is Professor in Social Work at Linköping University, Sweden. He has an academic background in political science and cultural studies. Among his primary research interests are the politics of inclusion/exclusion, citizenship and democracy. Currently, his research is mainly oriented towards the formation of citizenship and the struggles for defining citizenship, in the context of the multi-ethnic city.

Fredrik Sandberg is senior lecturer in adult education at Linköping University, Sweden. His primary research interests concerns adult education, citizenship, and recognition. He is the currently the secretary general of the European Society for Research on the Education of Adults (ESREA) and he is one of the founding editors of Confero: essays on Education, Philosophy and Politics. 